\title{
Damjan Francetić
}

Antirealizam i

pitanje napretka znanosti.

O konceptualnom relativizmu

Thomasa Kuhna

Metafilozofija i pitanja znanstvene metodologije, ur. B. Mikulić i M. Žitko, Zagreb: Filozofski fakultet Sveučilišta u Zagrebu, 2020, str. 183-209 EMAIL: damjan.francetic@yahoo.com 


\section{SAŽETAK}

Cilj je rada pokušati dati antirealističko objašnjenje napretka i uspješnosti znanosti na temelju konceptualno-relativističke interpretacije jednog dijela rane teorije Thomasa Kuhna koji se naziva problemom novog svijeta, a u kojem Kuhn tvrdi da se nakon znanstvene revolucije mijenja svijet u kojem znanstvenici žive i djeluju. U prvom ću dijelu rada stoga izložiti konceptualno-relativističku interpretaciju toga problema, prema kojoj su ono što se u ovom kontekstu znanstvenom revolucijom mijenja zapravo konceptualne sheme, tj. opći okvir kroz koji znanstvenici konceptualiziraju i interpretiraju iskustvene podatke. Zatim ću se, u drugom dijelu rada, osvrnuti na pitanje nesumjerljivosti kao nezaobilaznog elementa kako konceptualnog relativizma tako i Kuhnove teorije znanosti općenito. U trećem ću se dijelu rada okrenuti pitanju znanstvenog napretka kao jednom od glavnih eksplanatornih problema za antirealizam. Eksplicirat ću na koji je način znanost uspješna i u čemu se znanstveni napredak sastoji, a potom pokušati dati odgovor može li, i na koji način, kuhnovski konceptualno-relativistički model pružiti antirealističko objašnjenje napretka i uspješnosti znanosti. To ću objašnjenje na kraju pokušati produbiti uzevši u obzir metametodološku raspravu o vrijednostima koje vode znanstvenu praksu te pitanje na koji način eksterni faktori utječu na znanost. 
Antirealism and the Issue of Scientific Progress. On Thomas Kuhn's Conceptual Relativism

The goal of the paper is to provide an antirealist explanation of scientific progress and success based on a conceptual relativist interpretation of one aspect of Thomas Kuhn's early theory, the 'new-world problem', where Kuhn claims that paradigm change includes a change of the world in which the scientists live and work. In the first part of the paper, I will discuss a conceptual relativist interpretation of the new-world problem. According to that interpretation, what actually changes in a scientific revolution are conceptual schemes, i.e. the general framework through which the scientists conceptualize and interpret empirical data. I will then, in the second part of the paper, focus on incommensurability, a crucial element of conceptual relativism, as well as Kuhn's theory of science in general. In the third part of the paper I will turn to the question of scientific progress as one of the main explanatory challenges for antirealism. I will clarify in what way science is successful and what scientific progress consists in, and then try to give an answer to the question if and in what way the Kuhnian conceptual relativist model can provide an antirealist explanation of scientific progress and success. I will lastly try to augment that explanation by taking into consideration the metamethodological discussion about the values that guide scientific practice and the question in what way external factors influence science. 


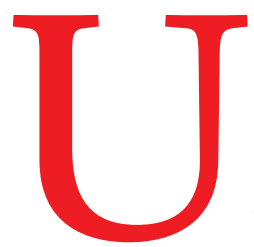

raspravama o realizmu i antirealizmu u filozofiji znanosti središnje mjesto zauzimaju problemi znanstvenog napretka i uspješnosti znanosti, koji pripadaju i u repertoar tipičnih pitanja metafilozofije i metametodologije. Upravo je činjenica izuzetnog napretka znanosti i tehnologije u proteklih nekoliko stoljeća jedan od glavnih razloga zašto mnogi filozofi zastupaju poziciju znanstvenog realizma koja tvrdi da su naše najbolje znanstvene teorije (približno) istinite te da znanost sve više i sve bolje opisuje svijet kakav on uistinu jest. Ako pak ne bi bilo tako, tj. ako znanstvene teorije nisu barem približno istinite, uspjeh znanosti bio bi ravan čudu, kako je to ustvrdio Hilary Putnam u klasičnoj verziji ovog argumenta, koji se stoga naziva 'argumentom bez čuda' (no-miracle argument). ${ }^{01} \mathrm{Uz}$ to, osim što uspjeh znanosti predstavlja jedan od temelja znanstvenog realizma, on predstavlja i jedan od ključnih problema za antirealizam - antirealistički pristupi stoje pred izazovom objašnjavanja evidentnog napretka znanosti. Istovremeno, i sam znanstveni realizam u ovom segmentu stoji pred značajnim izazovima. Naime, postoji cijeli niz teorija koje su u svoje vrijeme bile veoma uspješne i široko prihvaćene u znanstvenoj zajednici, a koje su danas potpuno odbačene i smatraju se pogrešnima. $\mathrm{Na}$ tom temelju antirealisti često tvrde da je moguće da su i danas općeprihvaćene teorije pogrešne i da će u nekom trenutku biti odbačene, što se naziva pesimističkom indukcijom iz povijesti znanosti. ${ }^{02}$ No, bez obzira na probleme s kojima se realizam susreće, napredak i uspješnost znanosti predstavljaju jedan od najvećih eksplanatornih problema za antirealizam.

U ovom ću radu pokušati dati jedan antirealistički odgovor na taj problem, i to na temelju konceptualno-relativističke interpretacije jednog dijela rane teorije Thomasa Kuhna, iznesenog ponajprije $u$ desetom poglavlju Strukture znanstvenih revolucija, u kojem Kuhn tvrdi da se promjenom paradigme mijenja i svijet u kojem znanstvenici žive

01 Putnam (1975): Mathematics, Matter, and Method, 73.

02 Klasičan je tekst o ovom problemu Laudan (1981): "A Confutation of Convergent Realism”. Za suvremeni pregled kasnije rasprave o historijskim argumentima protiv znanstvenog realizma v. Vickers (2018): "Historical challenges to realism". Za kritike argumenta bez čuda koje se ne temelje na historijskim protuprimjerima v. Wray (2018): "Success of science as a motivation for realism". 
i djeluju. ${ }^{03}$ Ian Hacking je taj problem nazvao problemom novoga svijeta (new-world problem). ${ }^{04} \mathrm{U}$ prvom ću se dijelu rada posvetiti analizi spornog poglavlja SZR. Najprije ću se pozabaviti dvjema relevantnim interpretacijama ovog poglavlja, kantovskom interpretacijom Paula Hoyningen-Huenea te taksonomskom interpretacijom Iana Hackinga, a potom zastupati treću, konceptualno-relativističku interpretaciju. Zatim ću se, u drugom dijelu rada, kratko okrenuti nesumjerljivosti kao nezaobilaznoj temi u raspravama kako o Kuhnu, tako i o konceptualnom relativizmu. Konačno, u trećem ću se dijelu rada okrenuti problemu znanstvenog napretka u antirealizmu. Najprije ću eksplicirati u čemu bi se znanstveni napredak sastojao, a zatim pokušati dati odgovor na pitanje kako pozicija iznesena u prvim dvama dijelovima rada može objasniti napredak i uspješnost znanosti. To ću objašnjenje pokušati produbiti uzevši u obzir metametodološku raspravu o vrijednostima koje vode znanstvenu praksu te pitanje na koji način eksterni faktori utječu na znanost, a pritom ću se dotaknuti i pitanja imaju li filozofske rasprave o metodologiji i metametodologiji znanosti normativnu relevantnost za samu znanstvenu praksu. ${ }^{05}$

Okrenimo se stoga najprije Kuhnu. Među brojnim kontroverznim dijelovima SZR spomenuto deseto poglavlje, naslova "Revolucije kao promjene viđenja svijeta" ("Revolutions as Changes of World-View”), zauzima posebno mjesto. Ono je bilo meta snažnih kritika. ${ }^{06}$ Ovaj je dio knjige sve u svemu prilično nejasan, a ni samom Kuhnu, kao što ćemo uskoro vidjeti, nije bilo sasvim jasno što želi reći. Nedostatak jasnoće zajedno s radikalnošću iznesenih tvrdnji glavni je izvor negativnih kritika, ali i relativne zanemarenosti ovog dijela Kuhnove teorije

03 Kuhn (2002): Struktura znanstvenih revolucija (nadalje pod kraticom SZR $\mathrm{s}$ brojem stranice).

04 Hacking (1993): "Working in a New World: The Taxonomic Solution", 276.

05 U ovom ću se radu baviti prirodnim znanostima, budući da one i jesu u središtu pozornosti Thomasa Kuhna, a osim toga nisam siguran mogu li se zaključci ovog rada poopćiti s prirodnih na društvene i humanističke znanosti, dok bi rasprava o tome prelazila granice ovoga rada.

06 Tako primjerice Peter Godfrey-Smith (2003): Theory and Reality. An Introduction to the Philosophy of Science, 96, piše: "Chapter X is the worst material in Kuhn's great book. It would have been better if he had left this chapter in a taxi, in one of those famous mistakes that authors are prone to." 
među filozofima znanosti. ${ }^{07}$ Osnovna je tvrdnja desetog poglavlja SZR da znanstvenici različitih paradigmi nakon znanstvene revolucije žive i rade u drugačijem svijetu:

"U jednom smislu, koji nisam u stanju dalje eksplicirati, zastupnici suparničkih paradigmi prakticiraju svoje struke u različitim svjetovima (...) Radeći u različitim svjetovima dvije skupine znanstvenika vide različite stvari i onda kad s iste točke gledaju u istom smjeru.”os

Za početak, treba naglasiti da i sam Kuhn priznaje da ne donosi razrađenu teoriju, već najbolje što u tome trenutku može - a ta je mogućnost vrlo ograničena - pokušava eksplicirati uvide do kojih je došao proučavajući povijest znanosti. ${ }^{09}$ Nadalje, iako tvrdi da znanstvenici nakon znanstvene revolucije žive u svijetu različitom nego što je bio prije nje, Kuhn tvrdi i da se svijet znanstvenom revolucijom ne mijenja: "Što god mogao tada vidjeti, znanstvenik poslije revolucije još uvijek gleda onaj isti svijet." ${ }^{.0}$ Ovu proturječnost Kuhn ne rješava, kako u SZR, tako ni u kasnijim tekstovima. Cilj je stoga dati interpretaciju koja tu proturječnost uspijeva riješiti, te će se, kao što je već rečeno, zastupati konceptualno-relativistička interpretacija, naime da promjena paradigme znači i promjenu konceptualne sheme na temelju koje znanstvenici interpretiraju iskustvene podatke. Neke Kuhnove tvrdnje ukazuju na opravdanost ovakve interpretacije, primjerice kada piše da je znanstvena revolucija "pomicanje one pojmovne mreže kroz koju znanstvenici promatraju svijet". ${ }^{11} \mathrm{Ali}$, ako i jest bio na tom tragu,

07 Hacking (1993), 275: "Of all Thomas Kuhn's themes, the one that is most resolutely avoided in the polite company of American philosophers is precisely the one that most attracts the casual reader dipping into The Structure of Scientific Revolutions. I mean the idea that after a revolution we live in a different world."

08 SZR 159 (kurziv moj).

09 Za biografske podatke o tome kako je istraživanje povijesti znanosti Kuhna dovelo do ovih stavova v. Kuhn (2000): The Road Since Structure, 15-17 (nadalje pod kraticom RSS s brojem stranice), a za dodatne napomene vezane za proučavanje povijesti znanosti i 'različite svjetove' v. RSS 58-65.

10 SZR 138-139.

11 SZR 113. Ova je tvrdnja vjerojatno glavni razlog zašto se Kuhna često svrstava u konceptualne relativiste, iako se uglavnom ne eksplicira što bi kuhnovski konceptualni relativizam točno podrazumijevao ni koje bi bile njegove specifičnosti. 
Kuhn svoju teoriju nije dalje razvijao u ovom smjeru.

Budući da je konceptualni relativizam vrlo kontroverzna pozicija, ne postoji slaganje oko toga što bi taj pojam podrazumijevao, pa ću zato ovdje samo u kratkim crtama prikazati o čemu je riječ. Općenito govoreći, konceptualni relativizam je pogled koji smatra da dvije nesumjerljive konceptualne sheme mogu biti jednako adekvatni kognitivni alati. ${ }^{12}$ Konceptualne sheme su, riječima Donalda Davidsona, načini organiziranja iskustva, sustavi kategorija koji daju formu sirovim podacima osjeta, točke gledišta s kojeg pojedinci, kulture i razdoblja promatraju svijet. ${ }^{13}$ Konceptualna shema govori pojedincu od kojih se entiteta stvarnost sastoji, koja su njihova svojstva i na koji način oni djeluju jedan na drugoga. Pritom se može raditi samo o nekom odsječku stvarnosti kao i o stvarnosti u cjelini. Okrenimo se stoga najprije interpretaciji desetog poglavlja SZR te pokušajmo odgovoriti na ova pitanja. ${ }^{14}$

\section{Interpretacije problema novog svijeta}

Jedna je utjecajna interpretacija Kuhnovih tvrdnji o promjeni znanstvenikova svijeta nakon revolucije kantovska koju je iznio i razradio Paul Hoyningen-Huene. ${ }^{15}$ Prema Hoyningen-Hueneu, svijet koji uvijek ostaje isti, kantovski je svijet po sebi, a svijet koji se revolucijom mijenja svijet je pojava; znanstvenici različitih paradigmi utoliko djeluju u različitim 'pojavnim svjetovima' (Erscheinungswelten). Osnovna je razlika između Kuhna i Kanta što kod Kuhna ima više mogućih pojavnih svjetova, što se oni mijenjaju znanstvenim revolucijama i što su relativni s obzirom na vodeću paradigmu, dok je kod Kanta pojavni

12 Taylor (2011): “Conceptual Relativism”, 159.

13 Davidson (1973): "On the Very Idea of a Conceptual Scheme”, 5.

14 Valja napomenuti da je konceptualni relativizam bio snažno kritiziran kao neodrživ, a klasičnu i najutjecajniju kritiku iznio je Davidson u navedenom tekstu. Najpoznatiji odgovor Davidsonu dao je Putnam (1987): “Truth and Convention: On Davidson's Refutation of Conceptual Relativism”. Za nešto drukčije obrane konceptualnog relativizma i konceptualnih shema v. Lynch (1997): “Three Models of Conceptual Schemes” te Wang (2009): “On Davidson's Refutation of Conceptual Schemes and Conceptual Relativism”. Detaljnije ulaženje u ovu raspravu prešlo bi granice ovoga rada.

15 Hoyningen-Huene (1989): Die Wissenschaftsphilosophie Thomas S. Kuhns, poglavlja 2 i 3 , posebno odjeljak 2.1. 
svijet samo jedan. ${ }^{16}$ Pitanje je ipak koliko nam ova interpretacija pomaže u razumijevanju Kuhna. Kod Kanta je naime način nastajanja pojava, pa onda i pojavnog svijeta, jasno razrađen - pojave nastaju pod uvjetima prostora i vremena kao čistih formi osjetilnosti, s jedne, i kategorija kao pojmova čistog razuma, s druge strane, a nužan je uvjet spoznaje transcendentalno jedinstvo apercepcije. Kod Kuhna, međutim, nema takvog utemeljenja kao ni razrade temelja 'pojavnog svijeta. ${ }^{17} \mathrm{U}$ izostanku toga, govor o različitim pojavnim svjetovima kod Kuhna može biti koliko-toliko jasan samo u analogiji prema Kantu. Problem je još veći kada se u obzir uzme činjenica da je Kuhnova pozicija zapravo veoma različita od Kantove. Iako je i sam Kuhn svoju poziciju u kasnoj fazi karijere opisivao kao kantovstvo s promjenjivim kategorijama, takav je opis neadekvatan. ${ }^{18}$ Naime, dok se Kantove kategorije tiču uvjeta same spoznaje, kategorije relevantne za Kuhnovu teoriju pripadaju sasvim drugoj domeni — one se uvijek odnose na vanjski svijet. Dok Kant govori o kategorijama kauzalnosti i ovisnosti, inherencije i subzistencije, ili pak mogućnosti, nužnosti itd., Kuhn se bavi kategorijama kao što su planeti, sateliti, kisik, flogiston i sl. Također, kada se bavi prostorom i vremenom, Kuhn se bavi samo razlikama koncepcije prostora i vremena u klasičnoj te $\mathrm{u}$ relativističkoj paradigmi, ali prostor i vrijeme uvijek ostaju izvanjski subjektu, dakle sasvim suprotno nego što je slučaj kod Kanta. Stoga nije moguće opisati Kuhnovu poziciju kao kantovstvo s relativiziranim, tj. promjenjivim kategorijama - kantovske i kuhnovske kategorije odnose se na sasvim različite stvari. Nasuprot tome, pojam svijeta

16 Usp. Hoyningen-Huene (1989): 46-47.

17 Ova je tvrdnja posebno istinita za SZR; nešto blizu utemeljenju 'pojavnih svjetova' Kuhn će dati tek pri kraju karijere kada bude govorio o leksikonu, ali i to će ostati slabo eksplicirano (usp. Kuhn (1993):

"Afterwords", 315, 324-326, 330-331). Treba napomenuti da Kuhn čak i u tom kasnom radu govori o različitim svjetovima različitih znanstvenika (ibid. 319, 335-336), ali ni tada to ne ide dalje od metafore.

18 V. npr. RSS 264. Kuhnovo naglašavanje paralela između svoje teorije s Kantovom nastalo je barem djelomično pod utjecajem HoyningenHuenea - naime, Hoyningen-Huene je prilikom izrade svoje monografije o Kuhnu s njim bio u bliskom kontaktu. Za ovu situaciju instruktivan je i komentar Alexandera Birda: "I suspect that Kuhn was himself influenced by Hoyningen-Huene's giving his earlier thought a (particular species of) philosophical sophistication that it did not really have." Bird (2012): “The Structure of Scientific Revolutions and its Significance: An Essay Review of the Fiftieth Anniversary Edition”, 869. 
po sebi, u smislu svijeta kakav je neovisno o djelatnosti spoznajnog subjekta, može se zadržati, a u tome ću ga smislu nadalje i koristiti .

Problem s analogijom Kuhnovih različitih svjetova i Kantovih pojava sastoji se dakle u tome što su razlike između Kanta i Kuhna prevelike da bi se na toj analogiji mogla graditi interpretacija, pogotovo s obzirom na nedostatak neke vrste utemeljenja 'pojavnih svjetova' kod Kuhna. Što se tiče same interpretacije Hoyningen-Huenea, valja spomenuti da on nudi i detaljan opis 'konstitucije pojavnih svjetova' kod Kuhna čiji su ključni element 'odnosi sličnosti', na temelju kojih svaki stanovnik 'pojavnog svijeta' zna prepoznati objekte, međusobnu srodnost ili nesrodnost objekata, te prepoznati primjerice neki prirodni proces kao poseban slučaj nekog drugog procesa. ${ }^{19}$ Međutim, 'pojavni svjetovi' sami po sebi uopće nisu potrebni za raspravu o odnosima sličnosti - dovoljno je reći da različite paradigme podrazumijevaju različite odnose sličnosti i time započeti analizu. Svrha uvođenja kantovskoga momenta kod Hoyningen-Huenea je eksplanatorna - on želi razjasniti Kuhnove tvrdnje o promjeni znanstvenikova svijeta nakon znanstvene revolucije. Ta nam analogija doduše može biti heuristički korisna i poslužiti kao početna točka interpretacije time što ističe dvojnost $\mathrm{u}$ Kuhnovom pojmu svijeta. ${ }^{20}$ Ali iz gore navedenog proizlazi da kantovska interpretacija - barem ona koju je iznio Hoyningen-Huene - ne može ni biti nešto više od korisne analogije. Kuhnove tvrdnje da znanstvenici različitih paradigmi žive u različitim svjetovima ostaju nejasne i nakon uvođenja analogije prema Kantu, budući da je nejasno kako bi se Kantova teorija trebala primijeniti na Kuhnov slučaj, a Hoyningen-Huene ne nudi u pozivanju na Kanta ništa više od navedene analogije.

Uz kantovsku, najvažnija je interpretacija problema novog svijeta kod Kuhna taksonomska interpretacija Iana Hackinga. Prema Hackingu, problem razumijevanja Kuhnova teksta rješava se ako uzmemo da se ovdje radi o jednom obliku nominalizma. Za nominalizam općenito jedino su realni individualni objekti, a kategorije u koje ih svrstavamo potječu iz ljudske aktivnosti klasificiranja. Individualni predmeti, dakle, postoje neovisno o umu, a klasifikacija je ta koja je ovisna o aktivnostima našeg uma. Primijenivši ovo rješenje na problem novoga svijeta, Hacking zaključuje:

19 Hoyningen-Huene (1989): poglavlje 3., posebice odjeljci 3.2 i 3.3.

20 Ibid. 41-43. 
"Svijet se ne mijenja, ali mi radimo u novom svijetu. Svijet koji se ne mijenja svijet je individua. Svijet u kojem i s kojim radimo svijet je vrstâ. Svijet vrstâ se mijenja; svijet individua ne. Nakon revolucije, znanstvenik radi u svijetu novih vrstâ." ${ }^{11}$

Dakle, nakon znanstvene revolucije mijenja se taksonomija - raspodjela individua po kategorijama. Same se pak individue ne mijenjaju. ${ }^{22}$ Ova interpretacija predstavlja, po pitanju problema novog svijeta, korak naprijed u odnosu na Kuhna budući da nudi jasno i originalno objašnjenje njegovih tvrdnji. ${ }^{23}$

Međutim, čini se da nam SZR daje mogućnost da u interpretaciji desetog poglavlja odemo i korak dalje od Hackinga. Vratimo se ključnom citatu: "Radeći u različitim svjetovima, dvije skupine znanstvenika vide različite stvari i onda kad s iste točke gledaju $\mathrm{u}$ istom smjeru." ${ }^{24}$ Uzmimo za primjer nekog aristotelovca, Galilea i njihalo. Dok aristotelovac, gledajući u kamen zavezan za konopac koji se klati naprijed-natrag, vidi tijelo koje je svojom prirodom pokrenuto iz višeg

21 Hacking (1993): 306 (prijevod moj). Usp. "The world does not change, but we work in a new world. The world that does not change is a world of individuals. The world in and with which we work is a world of kinds. The latter changes; the former does not. After the revolution, the scientist works in a world of new kinds.”.

22 Hacking (1983): Representing and intervening, 110 također tvrdi da kod Kuhna postoji razlika između 'predznanstvenih' kategorija koje se temelje na neposrednom empirijskom iskustvu i kategorija nastalih unutar neke znanosti: "[Kuhn] can equally assert that many of our prescientific categories are natural kinds: people and grass, flesh and horseflesh. The world simply does have horses and grass in it, no matter what we think, and any conceptual scheme will acknowledge that." Međutim, pitanje je odgovaraju li ovakve tvrdnje Kuhnovim stavovima. Neki njegovi komentari napisani u vrijeme izlaska drugog izdanja SZR upućuju na suprotno, npr.: "Pojedinci koji su obrazovani u različitim društvima ponašaju se u izvjesnim prigodama kao da su vidjeli različite stvari”. (SZR, 201) Usp. također Kuhn (1977): The Essential Tension, 308-309 (nadalje pod kraticom ET s brojem stranice).

23 Hoyningen-Hueneova knjiga ovdje je vrlo korisna dopuna Hackingu. Naime, iako Hoyningen-Hueneova analiza problema novog svijeta ne donosi ništa novoga u odnosu na Kuhna osim analogije prema Kantu, njegova sistematska analiza raštrkanih Kuhnovih napisa o odnosima sličnosti na jednom mjestu sažima specifično kuhnovski pogled na taksonomiju u znanosti. Usp. Hoyningen-Huene (1989): 78-88.

24 SZR 159. 
u niži položaj, ali mu u tome smeta konopac pa ono u taj položaj stiže otežano, Galileo vidi njihalo, tj. tijelo koje je gotovo uspjelo u vječnom ponavljanju istog kretanja. Aristotelovac, Kuhnovim rječnikom, 'vidi' kamen koji otežano stiže u niži položaj, a Galileo 'vidi' njihalo, iako obojica 'gledaju' u isti predmet. Na koji se način može eksplicirati ova razlika gledanja i viđenja? Smatram da aristotelovac i Galileo vide jedno te isto u smislu oblika, dimenzija, smjera kretanja promatranog predmeta i sl., ali različito interpretiraju viđeno, odnosno oni upisuju različita svojstva u taj predmet: aristotelovac to tijelo na konopu smatra tijelom kojem je otežan pad u 'prirodno' stanje mirovanja u nižoj točki, a Galileo u njemu uopće ne vidi nešto slično tome, već predmet koji je gotovo uspio beskonačno ponoviti isto kretanje; dakle, za njega nema govora o tome da je to tijelo 'njegova vlastita priroda' 'pokrenula' u niži položaj. Tom različitom interpretacijom bazičnih elemenata tog predmeta nastaje procjep koji se potom sve više širi — naime, različita interpretacija tih osnovnih elemenata određuje na koji će se način ti predmeti dalje ispitivati, kakve će se pravilnosti u njima pronalaziti i do kojih će se zaključaka doći:

"Gledajući ograničavani pad, aristotelovac bi mjerio (ili barem raspravljao — oni su rijetko mjerili) težinu kamena, visinu do koje je bio podignut, kao i vrijeme koje mu je potrebno da dođe u stanje mirovanja. Zajedno s otporom okoline, to su bile konceptualne kategorije koje je razvijala aristotelovska znanost koja se bavila tijelom koje pada. Normalno istraživanje koje se vodilo tim kategorijama nije moglo stvoriti one zakone koje je otkrio Galileo. (...) [Galileo] je (...) mjerio samo težinu, promjer, kutni pomak i vrijeme jednog njihanja, dakle upravo one podatke interpretacijom kojih se može doći do Galileovih zakona za njihalo. (...) Pravilnosti koje za jednog aristotelovca nisu mogle postojati (i za koje zapravo priroda nigdje ne pruža primjere) za nekog tko je kamen koji se njiše vidio na isti način kao i Galileo predstavljale su posljedice neposrednog iskustva."25

Međutim, sam je Kuhn inzistirao da se ovdje ne radi o interpretaciji. ${ }^{26} \mathrm{Za}$ Kuhna je interpretacija proces promišljanja i odlučivanja

25 SZR 132-133.

26 “Što je još važnije, proces pomoću kojeg pojedinac ili zajednica prelaze s ograničavanog pada na njihalo ili sa deflogistoniziranog zraka na kisik, nije sličan interpretaciji. Kako bi taj proces mogao dovesti do 
[deliberative process] u kojem biramo među alternativama i u kojem tražimo i primjenjujemo kriterije i pravila. ${ }^{27}$ Nasuprot tome, smatram da uvođenjem figure temeljne interpretacije kao upisivanja različitih svojstava $u$ isti predmet možemo dati smisleno tumačenje Kuhnovih tvrdnji. Ključna je razlika temeljne interpretacije i Kuhnova pojma interpretacije u tome što bi temeljna interpretacija, prema relevantnim dijelovima u SZR, bila nužno nesvjesna; ipak nema razloga zašto ne bi barem načelno postojala mogućnost da se namjerno pokuša doći do nove interpretacije, npr. u razdoblju krize. Nadalje, ovako shvaćena temeljna interpretacija sastavni je dio percepcije ili čak, zaoštreno, njen preduvjet. ${ }^{28}$ Osim toga, ona služi kao temelj za normalni posao interpretacije znanstvenih podataka u periodu normalne znanosti:

"Galileo je interpretirao promatranja koja se odnose na njihalo, Aristotel promatranja koja se tiču kamenja koje pada, Musschenbroek promatranja koja se odnose na bocu napunjenu elektricitetom, a Franklin promatranja koja se tiču kondenzatora [tj. svaki od njih je kretao od drukčije temeljne interpretacije; dod. D.F.]. Ali, svaka od ovih interpretacija pretpostavljala je neku paradigmu [tj. temeljnu interpretaciju; dod. D.F.]. (...) Kad paradigma postoji, interpretacija podataka centralna je za pothvat njenog istraživanja." ${ }^{29}$

U kojem je smislu takva interpretacija temeljna? Kao prvo, temeljna je vremenski, na početku razvoja paradigme, jer se takvom drukčijom interpretacijom jednog odsječka stvarnosti stvara mogućnost razvoja nove, drugačije, i eventualno uspješnije paradigme od dosadašnje. Zatim - a ovo pogotovo vrijedi kada je paradigma već razvijena — ona je (zajedno s taksonomskom podjelom stvarnosti) temelj iz kojega znanstvenici polaze u svom radu, kako teorijskom, tako i eksperimentalnom. Primjerice, znanstvenici su u proučavanju svjetlosti polazili od 'činjenice' da svjetlost jest čestica ili pak svjetlost jest val, a potom na tom temelju vršili određene proračune, mjerili određene stvari itd.

takvog prijelaza u nedostatku utvrđenih podataka koje bi znanstvenici interpretirali? Znanstvenik koji je prihvatio novu paradigmu više je sličan čovjeku koji nosi naočale s lećama koje preokreću sliku nego na interpretatora." SZR, 131 (kurziv moj).

27 Usp. SZR 203.

28 SZR 123. Za utjecaj N. R. Hansona i Gestalt-psihologije na Kuhna usp. B. Kožnjak (2013): Eksperiment i filozofija, str. 78-88.

29 SZR, 131-132. 
Konačno, ona je temeljna u obrazovanju znanstvenika — studenti uče da je onaj objekt njihalo, a ne kamen koji s teškoćom dolazi u prirodni položaj, ili je kisik, a ne flogiston i sl.

Jedan odsječak stvarnosti, dakle, omogućuje više različitih interpretacija. ${ }^{30}$ Ključno je pritom da on i ograničava moguće interpretacije:

"Radeći u različitim svjetovima dvije skupine znanstvenika vide različite stvari i kada s iste točke gledaju u istom smjeru. To opet ne znači da one mogu vidjeti što god im se sviđa. Obje skupine gledaju na svijet koji im je na raspolaganju, a ono što gledaju nije se promijenilo." ${ }^{31}$

Na primjeru njihala možemo pokušati natuknuti na koji način sâm svijet ograničava moguće interpretacije. Iako, kako je već spomenuto, u kamen koji se njiše na konopcu i aristotelovac i Galileo upisuju različita svojstva, oni ipak vide isto u smislu oblika, dimenzija, smjera kretanja i sl. Nadalje, oni moraju uzeti u obzir i ograničenost kamena koji se njiše; nitko ne može, barem ako želi biti ozbiljno shvaćen, predložiti takvu temeljnu interpretaciju prema kojoj se radi o tijelu koje se giba beskonačno pravocrtno, ili koje pada bez prepreke i sl.

Hackingovo taksonomsko rješenje i figura temeljne interpretacije nisu u kontradikciji; dapače, one čine elemente onoga što možemo nazvati kuhnovskom konceptualnom shemom. Nju dakle s jedne strane čini temeljna interpretacija koja omogućava daljnju normalnu interpretaciju podataka: primjerice, onaj objekt jest njihalo, ona linija u komori jest trag elektrona, onaj plin jest kisik. S druge strane, i usko povezano s tim, kuhnovsku konceptualnu shemu sačinjavaju kategorije kojima se predmeti grupiraju na određeni način, kao primjerice $u$ kopernikanskoj kategorizaciji nebeskih tijela: postoje (između ostalog) zvijezde, planeti i sateliti; Sunce spada među zvijezde, Zemlja i Jupiter među planete, a Mjesec među satelite. Šire govoreći, ova dva elementa čine osnovnu ontologiju konceptualne sheme, koja se razrađuje razradom paradigme i koju i kasniji naraštaji znanstvenika usvajaju preuzevši paradigmu, a koja znanstvenicima govori od kojih se entiteta i procesa stvarnost sastoji te koja su njihova svojstva. Razrada kon-

30 "Filozofi znanosti više su puta dokazali da se na jedan zadani zbir podataka može uvijek postaviti više od jedne teorijske konstrukcije. Povijest znanosti ukazuje na to da takve zamjene nije čak niti teško smisliti, posebno u ranim razvojnim fazama paradigme." SZR 87.

31 SZR 159 (kurziv moj). 
ceptualne sheme pak s vremenom može dovesti do značajne izmjene ontologije te konceptualne sheme. Primjerice, kada ga je Lavoisier prvi puta postulirao, kisik je za njega bio princip kiselosti, što je prilično različito od današnjeg razumijevanja kisika kao kemijskog elementa. Treba također naglasiti ulogu metafore u razvijanju temeljne interpretacije; znanstvenici često pronalaze rješenje anomalije nakon što vide sličnost $s$ nečim za što rješenje već postoji ili s nečim što im daje slikovit model koji im pomaže u rješavanju problema — Kuhnovim rječnikom, oni uče vidjeti nešto kao nešto drugo. ${ }^{32}$ Sličnost je ključna i u obrazovanju znanstvenika unutar normalne znanosti, kada se niz problema uči riješiti na temelju sličnosti sa paradigmatskim primjerom. ${ }^{33}$

Konačno, treba eksplicirati u kojem odnosu konceptualna shema stoji prema pojmu paradigme. Kuhn je paradigmu nekoliko godina nakon SZR definirao kao disciplinarnu matricu koja se sastoji od simboličkih generalizacija (npr. F=ma), metafizičkih dijelova paradigmi (koji znanstveniku govore od čega se svijet sastoji, koja su svojstva tih sastavnih dijelova itd.), vrijednosti (o čemu će još biti riječi u zadnjem dijelu ovog rada) i uzornih primjera (što je ujedno bilo značenje zbog kojeg je Kuhn i uveo pojam paradigme). ${ }^{34}$ Konceptualne sheme bi odgovarale upravo drugom dijelu, metafizičkim dijelovima paradigmi; smatram da bi pojam konceptualne sheme mogao zamijeniti 'metafizičke dijelove paradigmi'. Osim toga, temeljna interpretacija kao element konceptualne sheme usko je povezana sa četvrtim segmentom disciplinarne matrice, naime uzornim primjerom, posebice $u$ obrazovanju znanstvenika.

Dosadašnja se rasprava izravno tiče jednog od ključnih problema filozofije znanosti, naime problema istinosnog sadržaja znanosti, odnosno pitanja govore li nam znanstvene teorije o tome kakav sam svijet zaista jest te je li povijest znanosti ujedno povijest približavanja istini. Predloženi kuhnovski model daje negativan odgovor - znanstvene teorije ne govore nam o tome kakav je svijet sam po sebi, a za svaki

32 “Thus, Planck's resonators were like Boltzmann's molecules, or Volta's battery cells were like Leyden jars, and resistance was like electrostatic leakage." RSS 30 (kurziv u originalu).

33 Usp. SZR 197, RSS 30-31, Hoyningen-Huene (1989): 77-83.

34 Radi se o "Postscriptu” drugom izdanju SZR te tekstu "Second Thoughts on Paradigms" objavljenom u ET 293-319. Iako su napisani gotovo istovremeno, eksplikacije pojma disciplinarne matrice u njima se ponešto razlikuju. Ja ću se držati onoga što je izneseno u "Postscriptu". 
skup podataka postoji više mogućih interpretacija; povijest znanosti nije povijest približavanja istini već zamjenjivanja jedne konceptualne sheme drugom te, općenitije, jedne paradigme drugom. ${ }^{35}$ Istovremeno, ovdje se ipak radi o umjerenom antirealizmu, utoliko što je sadržaj konceptualne sheme ipak ograničen vanjskim svijetom, tj. svaka je interpretacija podataka ipak interpretacija vanjskog svijeta.

\section{Nesumjerljivost}

Prije nego se okrenemo pitanju znanstvenog napretka, treba se kratko posvetiti drugom segmentu Kuhnove teorije koji je ključan za ovu temu - nesumjerljivosti. Naime, problem nesumjerljivosti, ako uzmemo u obzir historijat rasprava, neodvojiv je od rasprave o konceptualnim shemama i konceptualnom relativizmu. Konceptualni se relativizam obično definira kao pozicija koja tvrdi da postoji više adekvatnih nesumjerljivih konceptualnih shema. ${ }^{36}$ Najutjecajnija kritika ideje konceptualnih shema, već spomenuta Davidsonova, zapravo je prvenstveno kritika nesumjerljivosti, $i$ to nesumjerljivosti shvaćene kao neprevodljivosti, bilo potpune, bilo djelomične. ${ }^{37}$ Osim toga, nesumjerljivost je ključna i za Kuhnovu teoriju općenito, počevši sa SZR pa sve do kraja njegove karijere.

U SZR nesumjerljivost podrazumijeva, kao što i sama riječ kaže, da ne postoji jedno zajedničko mjerilo prema kojemu bi se različite paradigme mogle vrednovati — svaka paradigma koristi vlastite kriterije u procjeni kako same sebe, tako i suparničkih paradigmi. ${ }^{38} \mathrm{Kod}$ Kuhnova djela u cjelini nesumjerljivost se općenito može definirati kao nepostojanje jedinstvenog algoritma koji bi prisilio svako racionalno biće da, u situaciji u kojoj za isti skup pojava postoji nekoliko

35 Usp. SZR 87 i 178-181.

36 Hilary Putnam i, u nastavku na njega, Tim Button, zastupaju ideju više mogućih, ali sumjerljivih, konceptualnih shema, a toj poziciji daju naziv 'konceptualna relativnost' (conceptual relativity) u izravnom razgraničenju naspram konceptualnog relativizma (conceptual relativism), kojeg karakterizira tvrdnja o nesumjerljivosti. Usp. Putnam (2012): "From Quantum Mechanics to Ethics and Back Again”, 56-58 i Button, (2013): The Limits of Realism, poglavlja 18 i 19.

37 Za detaljnu Kuhnovu raspravu o odnosu nesumjerljivosti i neprevodljivosti v. "Commensurability, Comparability, Communicability" (RSS $33-57)$.

38 Usp. SZR 105 i 118-119. O jednom od izvora nesumjerljivosti u ovom smislu bit će riječi i u zadnjem dijelu ovoga rada. 
suparničkih teorija, odabere istu teoriju. ${ }^{39} \mathrm{Uz}$ različite kriterije procjenjivanja uspješnosti, svaka paradigma ima i određene metode koje se razlikuju od onih suparničke paradigme ${ }^{40}$, a osim toga za jednu paradigmu postoje određeni entiteti i procesi koji za suparničku paradigmu ne postoje (npr. flogiston, kisik). ${ }^{41}$ Ovaj posljednji segment Kuhn je kasnije detaljnije razradio kao nesumjerljivost značenja: promjenom paradigme neki pojmovi mijenjaju značenje (npr. pojmovi prostora i vremena u newtonovskoj i relativističkoj fizici), neki pojmovi se prestaju koristiti (npr. flogiston nakon kemijske revolucije), a neki novi pojmovi se uvode (npr. kisik). Nesumjerljivost značenja ima za posljedicu nemogućnost da se neki iskazi jedne paradigme izraze vokabularom druge paradigme, a da se pritom, $s$ jedne strane, njihovo značenje u potpunosti zadrži, a s druge strane da se ne uđe u kontradikciju s nekim iskazima koji vrijede u paradigmi u koju se prevodi. ${ }^{42}$ Primjer nemogućnosti zadržavanja potpunog značenja je flogiston - u osamnaestostoljetnoj kemiji flogiston je princip izgaranja, međutim, suvremena kemija ne poznaje kategoriju principa u onom smislu u kojem je ona vrijedila za kemiju 18. stoljeća. Stoga se u vokabularu suvremene kemije ne može izraziti iskaz 'flogiston je princip izgaranja, a posljedično ni bilo koji iskaz koji sadržava termin 'flogiston' ne može biti preveden, a da zadrži svoje cjelovito značenje. ${ }^{43}$ Za kasnog Kuhna, ovakvi su iskazi neizrecivi (ineffable) za nekoga tko se služi vokabularom nekompatibilne paradigme. ${ }^{44}$ Ova nemogućnost prevođenja - pri čemu se prevođenjem smatra postupak kojim se neki iskaz (u ovom slučaju iz jezika jedne teorije) jedan za jedan, bez ostatka, prenosi u drugi jezik - ipak ne znači da se pripadnici različitih paradigmi ne mogu razumjeti. Naime, pripadnik jedne paradigme

39 Usp. SZR 208.

40 SZR 114.

41 SZR 8o-83, 119. Valjda naglasiti da je kod Kuhna nesumjerljivost uvijek djelomična ( $\mathrm{tj}$. 'lokalna') - postoji određeni dio metoda koje su iste u različitim paradigmama, mnogi pojmovi imaju ista značenja itd.

42 Usp. RSS 15.

43 Usp. RSS $40-43$.

44 Kuhn (1993): 330. Ovdje su relevantne samo paradigme koje se odnose (barem u jednom dijelu) na isti odsječak stvarnosti, ali daju nekompatibilne interpretacije tog odsječka. Također, moguće je u jednu paradigmu naprosto preuzeti neke koncepte iz druge, ako oni nisu u kontradikciji s ostalim konceptima, usp. ibid. 319. 
može 'naučiti jezik' druge paradigme, odnosno, može usvojiti drugu konceptualnu shemu i to na način sličan onome kojim je naučio jezik svoje paradigme. ${ }^{45}$ Pritom je upravo djelomičnost nesumjerljivosti ključna - znanstvenik može usvojiti tuđu konceptualnu shemu zato što ima dovoljno toga zajedničkog sa zastupnicima druge paradigme te, polazeći od toga što s njima dijeli, može pokušati razumjeti ono u čemu se od njih razlikuje. To pak ne znači da će sami znanstvenici uspjeti u usvajanju druge konceptualne sheme - povijest znanosti puna je primjera slomova komunikacije (communication breakdown) između pripadnika različitih paradigmi. Tvrdi se samo da nemogućnost međusobnog razumijevanja nije nužna, ali kada se dogodi, nesumjerljivost je to što ju uzrokuje.

\section{Problem znanstvenog napretka}

Kako je na početku rada već rečeno, problem znanstvenog napretka, odnosno sve veća uspješnost znanosti, jedan je od glavnih eksplanatornih problema za antirealizam općenito, pa tako i za poziciju iznesenu u dosadašnjem radu. No, u čemu se točno sastoji uspješnost znanosti i u čemu to znanost napreduje?

Kao jedan od glavnih elemenata koji pokazuje uspješnost znanosti obično se navode uspješna eksperimentalna predviđanja na temelju teorija, kao što je Halley na temelju Newtonove teorije desetljećima unaprijed predvidio vrijeme povratka kometa koji je po njemu dobio ime. ${ }^{46}$ Poseban pak status zauzimaju nova predviđanja (novel predictions). Neka je predviđena činjenica nova za teoriju ako nije korištena u konstrukciji te teorije. Drugim riječima, ako netko na temelju neke teorije predvidi posljedicu koju dotad nitko nije očekivao (npr. postojanje nekog fenomena), a ta posljedica nije korištena u konstrukciji teorije, tada se radi o novom predviđanju. ${ }^{47}$ Nadalje, znanstvene teorije

45 Za detaljnu raspravu o učenju jezika teorije na primjeru newtonovske mehanike vidi RSS 65-75. Usvajanje nove konceptualne sheme ono je što povjesničari znanosti često moraju raditi kako bi mogli rekonstruirati značenje tekstova nastalih unutar ugašenih paradigmi (usp. RSS 58-63).

46 Usp. Wray (2018): 37.

47 Ibid. 38-39. Naravno, ovdje su relevantne one posljedice koje su eksperimentalno potvrđene; ovakva previđanja mogu i biti snažan razlog za odbacivanje teorije ako se eksperimentalno ne potvrde. Usp. također Kuhnov stav: "Izgleda da Einstein, na primjer, nije anticipirao da bi opća teorija relativnosti mogla s preciznošću objasniti dobro poznatu nepravilnost u kretanju Merkurovog perihela, te je doživio 
nisu uspješne samo u predviđanjima, već i u manipulaciji prirodom. Ta manipulacija može biti vrlo precizna, primjerice u proučavanju elementarnih čestica. ${ }^{48}$ Međutim, treba uzeti u obzir i koliko je snažno znanost u sprezi s tehnologijom transformirala svijet u posljednjih nekoliko stotina godina. Konačno, mnoge znanstvene teorije, primjerice teorija evolucije, veoma su eksplanatorno uspješne, tj. dobro objašnjavaju niz empirijskih nalaza. ${ }^{49} \mathrm{U}$ svim ovim poljima znanost napreduje - teorije s vremenom daju sve više predviđanja koja se potvrđuju, sposobnost manipulacije prirodom raste, a raste i eksplanatorna moć znanosti, dijelom zato što raste eksplanatorna moć pojedinih teorija, a dijelom jer raste i broj uspješnih teorija. Na ovom se temelju gradi već spomenuti argument bez čuda, prema kojem je, ako znanstvene teorije nisu barem približno istinite, tolik uspjeh i napredak znanosti ravan čudu. Antirealistima općenito, dakle, ostaje izazov objašnjavanja napretka znanosti, a s obzirom na konkretnu poziciju iznesenu u ovom radu, taj se problem može precizirati na sljedeći način: ako znanost ne razotkriva istinu svijeta po sebi, te povijest znanosti nije napredak prema konačnoj istini, već se sastoji od smjenjivanja jedne konceptualne sheme drugom, a za svaku je konceptualnu shemu u načelu moguća neka alternativna, jednako adekvatna, nesumjerljiva konceptualna shema - kako to da znanost ipak napreduje? ? $^{50}$

Smatram da kuhnovski konceptualno-relativistički pristup na ovaj izazov može adekvatno odgovoriti. Za početak, na primjeru njihala vidjeli smo u kojem se smislu može tvrditi da vanjski svijet ograničava sadržaj konceptualnih shema - iako za isti odsječak stvarnosti u načelu postoji više mogućih interpretacija i taksonomija, pa stoga i više mogućih ontologija, ono što se na različite načine interpretira ipak je vanjski svijet. Konstrukcija konceptualnih shema je ograničena

primjereni trijumf kada je teorija to objasnila.” SZR, 164 .

48 Wray (2018): 43.

49 Vickers (2018): 52.

50 Usp. nešto drukčiju formulaciju ovog problema: "This raises the prospect that the history of science is no more than the complicated tale of wandering over the centuries among the many different worlds 'constructed' by different observers over the centuries, a series of worlds none of which is any better than the rest, since science itself is not cumulative, in the way it would be if it were a way of discovering the world as it is." Rockmore (2006): "Kuhn, Different Worlds and Science as Historical", 182. 
vanjskim svijetom i stoga ne može biti sasvim proizvoljna, barem ako konceptualna shema hoće biti plauzibilna. Svaka konceptualna shema koja se, primjerice, bavi predmetom koji nazivamo njihalo, mora uzeti u obzir barem njegovu ograničenost; nitko ne može tvrditi da kretanje Sunca, bez obzira bilo ono kategorizirano kao planet ili kao zvijezda, nema nikakve pravilnosti u odnosu na kretanje Zemlje; plin nastao zagrijavanjem crvenog živinog oksida ne može se koncipirati kao kruta tvar. Nadalje, u obzir treba uzeti neka svojstva znanstvenih revolucija koja je Kuhn iznio još u SZR. Nova paradigma — a pogotovo konceptualna shema kao dio 'zadužen' za ontologiju — ne mora samo objasniti ono što su za staru paradigmu anomalije, već mora objasniti i ono što stara paradigma jest uspješno objasnila. ${ }^{51}$ Također, ona mora dati znanstvenicima 'obećanje' da će se neriješeni problemi riješiti u budućnosti. ${ }^{52}$ Nadalje, nova paradigma mora dati nova predviđanja koja se mogu eksperimentalno provjeriti. Utoliko, nova paradigma mora biti šira od stare - mora objasniti veliku većinu onoga što stara paradigma jest uspješno objasnila te neke pojave koje stara paradigma ne može objasniti, kao i dati nova predviđanja. ${ }^{53}$ Osim toga, nove paradigme ne nastaju u vakuumu, već upravo kao pokušaj da se riješe neki konkretni problemi koje stara paradigma ne može riješiti. One se velikim dijelom baziraju na podacima stare paradigme, a često te podatke i reinterpretiraju. ${ }^{54}$

Dakle, napredak i uspješnost znanosti se s jedne strane objašnjavaju time što različite konceptualne sheme interpretiraju vanjski svijet, koji ograničava moguće interpretacije, a s druge strane tvrdnjom da nova paradigma, a s njom ni nova konceptualna shema, ne može biti prihvaćena u relevantnoj znanstvenoj zajednici ako ne predstavlja napredak u odnosu na staru paradigmu. Prihvaćanje nove konceptualne

51 Treba naglasiti da nova paradigma uglavnom ne rješava baš sve probleme koje je stara uspjela riješiti: "Iako nove paradigme rijetko ili nikad ne posjeduju sve mogućnosti svojih prethodnica, one obično zbog toga sačuvaju vrlo mnogo onih najkonkretnijih dijelova ranijeg dostignuća, a uz to uvijek dopuštaju i dodatna konkretna rješenja problema. (...) Često neki stari problemi moraju biti istjerani." SZR 178.

52 Usp. SZR 164-166.

53 Nova, neočekivana (i potvrđena) predviđanja također nisu garancija istinitosti neke teorije. Dapače, cijeli niz svojevremeno uspješnih, a danas odbačenih teorija imao je i uspješna nova predviđanja, usp. Wray (2018): 39.

54 Usp. SZR 20, 97, 150. 
sheme te, šire, paradigme, utoliko istovremeno označava i napredak znanosti, ili točnije, označava uvjerenje određene skupine znanstvenika da nova paradigma predstavlja napredak spram stare, budući da je moguće, iako nije pravilo, da se neka paradigma s vremenom pokaže kao slijepa ulica. ${ }^{55}$ Ova pozicija ne negira, dakle, napredak znanosti, već samo to da taj napredak treba objasniti približavanjem prema istini i sve većem otkrivanju strukture svijeta po sebi, te nudi alternativno objašnjenje. ${ }^{56}$ To se objašnjenje može produbiti ako u obzir uzmemo jedan dio Kuhnove kasnije teorije koji se tiče metametodologije znanosti, njegovu raspravu o vrijednostima kojima se pridaje različita težina (weighted values), koju je iznio u tekstu "Objectivity, Value Judgment, and Theory Choice" ${ }^{57}$ Kuhn smatra da se proučavajući povijest znanosti mogu identificirati vrijednosti koje znanstvenici dijele, u skladu s kojima formuliraju svoje teorije te koje uzimaju u obzir prilikom odabira između teorija. Posebno ističe pet vrijednosti - preciznost (posljedice teorije moraju se slagati s rezultatima eksperimenata i promatranja), konzistentnost (kako teorije unutar sebe, tako i s drugim teorijama), širina spektra (broad spectrum — posljedice teorije trebaju nadilaziti posebna promatranja, zakone i sl. koje je teorija konstruirana da objasni), jednostavnost te plodnost za daljnja istraživanja. ${ }^{58} \mathrm{Te}$ su vrijednosti glavni metametodološki principi koji vode i usmjeravaju znanstvenu praksu. Primjena je ovih vrijednosti, međutim, problematična. S jedne strane, vrijednosti same po sebi mogu biti ambivalentne - primjerice, jedna teorija može biti jednostavnija u smislu opsega i zahtjevnosti potrebnih izračuna, a druga u smislu entiteta koje postulira. S druge strane, vrijednosti mogu biti u međusobnom sukobu — jedna teorija može biti jednostavnija, ali manje precizna od druge; jedna može biti preciznija od druge, ali manje konzistentna s

55 Neki suvremeni fizičari primjerice smatraju da teorija struna u trideset godina nije postigla ništa više od pukih spekulacija i da je vrijeme da se odbaci. Usp. kratke tekstove "M-Theory/String Theory is the Only Game in Town", "String Theory” te "The 'Naturalness' Argument" koji su objavljeni u popularno-znanstvenom zborniku This Idea Must Die (Brockman 2015). Autori navedenih tekstova su fizičari i matematičari.

56 Negiranje da je znanost uspješna i da napreduje također je jedna od opcija. Usp. Kukla (1996): "Antirealist Explanations of the Success of Science", 299.

57 Tekst potječe iz 1973., a prvi put je objavljen u ET 320-339.

58 ET 321-322. Ova lista nije iscrpna, niti sama po sebi predstavlja novost $u$ odnosu na dotadašnju teoriju znanosti, kako Kuhn i sam ističe. 
ostalim teorijama itd..$^{59}$ Kada su vrijednosti u sukobu, na pojedinom znanstveniku ostaje kojim će i kakvim vrijednostima pridati veću težinu. Ovdje, kao integralni dio procesa konstruiranja, branjenja i odabira teorija, u igru ulazi onaj element kojeg tradicionalna filozofija znanosti smatra iracionalnim i irelevantnim za samu strukturu znanstvenih teorija, naime individualne preferencije znanstvenika. One mogu proizlaziti naprosto iz osobnosti znanstvenika, kao i iz njihovih dotadašnjih karijera, tj. onoga na čemu su radili i koliko su u tome bili uspješni — ako su većinu karijere posvetili određenoj teoriji i na njoj izgradili reputaciju, vjerojatnije je da će inzistirati na konzistentnosti novih predloženih teorija sa svojom teorijom. ${ }^{60} \mathrm{~S}$ ovim su povezani daljnji vanjski faktori koje Kuhn u tekstu ne spominje, poput vjerojatnosti dobivanja (ili zadržavanja) radnog mjesta ili pak financija za određeni projekt. Također, u ovom procesu relevantni su i općeniti intelektualni utjecaji, npr. filozofski, pa je tako njemački romantizam utjecao na prepoznavanje i prihvaćanje zakona očuvanja energije. ${ }^{61}$

Ipak, utjecaj navedenih čimbenika ograničavaju upravo navedene vrijednosti. Utoliko se one mogu promatrati kao minimalni uvjeti koje teorija mora ispuniti kako bi uopće ušla u obzir za ozbiljno razmatranje. Teorija ne mora ispuniti svaku od tih vrijednosti, ali mora barem neke od njih. Bez obzira na to koji bio konkretan razlog zašto neki znanstvenik radi na nekoj teoriji - bilo zbog prestiža, radnog mjesta, ili naprosto iz osobnih preferencija, kao u slučaju kasnije Einsteinove karijere - on mora dovesti teoriju u oblik koji će drugim znanstvenicima biti prihvatljiv da bi je uopće uzeli u razmatranje. ${ }^{62}$ Primjerice, iako je utjecaj neoplatonizma i hermetičke tradicije naveo Keplera da razvije kopernikansku astronomiju, njegova teorija ne bi imala nikakve šanse da nije razvio matematički aparat za precizno

59 Za detaljniju raspravu o ovom problemu te primjere iz povijesti znanosti usp. ET 322-324.

60 ET 324-325.

61 ET 325.

62 "Values like accuracy, consistency, and scope may prove ambiguous in application, both individually and collectively; they may, that is, be an insufficient basis for a shared algorithm of choice. But they do specify a great deal: what each scientist must consider in reaching a decision, what he may and may not consider relevant, and what he can legitimately be required to report as the basis for the choice he has made." ET 331. 
predviđanje položaja planeta. ${ }^{63}$ Istovremeno, te vrijednosti nisu i dovoljan uvjet — kada ih teorija ispunjava, u njenom eventualnom prihvaćanju ulogu igra još i čitav niz eksternih faktora. Utoliko 'eksterni' faktori, upravo suprotno od tradicionalnog pogleda prema kojem oni ne igraju ulogu u prihvaćanju teorija, ili je, ako igraju, riječ o 'lošoj znanosti', čine integralan dio znanosti. Među te eksterne faktore svakako ulazi i ono što su naglašavali socijalni konstruktivisti, naime da neka znanstvena teorija prevladava kao rezultat odnosa moći, interesa, institucionalnog okvira i sl. Međutim, čak i ako uvijek ili najčešće neka teorija prevlada zbog određenih odnosa moći, ta teorija ipak ne može biti bilo kakva, već mora ispunjavati minimalne uvjete. Među navedenim se uvjetima pak prvenstveno ističe preciznost - teorija (najčešće) mora u određenoj mjeri odgovarati eksperimentalnim rezultatima ili barem ne biti u izravnoj kontradikciji s njima. Konačno, valja naglasiti da su ove vrijednosti historijski nastale, te, osim što očito nisu neupitne za filozofe i sociologe znanosti, nisu neupitne ni za same znanstvenike. Znanstvenik može uvijek dovesti u pitanje neku od ovih vrijednosti. ${ }^{64}$ Štoviše, neka paradigma može u potpunosti zanemariti neku od vrijednosti koje su inače veoma značajne. Tako je primjerice kopenhaška interpretacija kvantne mehanike u potpunosti zanemarila eksplanatornu moć shvaćenu u determinističkom, kauzalnom smislu, što je bila ključna vrijednost klasične fizike. ${ }^{65}$ Ova pozicija, dakle, uzima u obzir različite eksterne faktore koji utječu na znanost, ali ih istovremeno ne apsolutizira. Da sažmem — iako su eksterni faktori integralan dio znanstvenog procesa, oni su sami ipak podložni određenim ograničenjima, a ta su ograničenja u najširem smislu vrijednosti, metametodološki principi za kojima se znanstvenici povode u svojem radu i u konstrukciji, razvoju i odabiru teorija.

Kao što je već rečeno, Kuhn izvodi listu vrijednosti iz povijesti znanosti - iz povijesne analize proizlazi da se znanstvenici u svome radu povode za navedenim vrijednostima. Međutim, ovime rasprava o metametodologiji znanosti još nije završena, budući da otvorenim

63 Usp. ET 325.

64 Usporedi kritiku vrijednosti jednostavnosti u tekstu "Aesthetic Motivation" u Brockman (2015).

65 Usp. Holland (1993): The Quantum Theory of Motion, xvii, 1. Za primjer rasprave fizičara o tome kojoj se vrijednosti treba pridati veća težina $u$ formuliranju teorije, eksplanatornoj moći ili sposobnosti predviđanja, v. ibid. 10-11. 
ostaje pitanje opravdanja - što je to zbog čega možemo tvrditi da se znanstvenici i trebaju povoditi upravo za tim vrijednostima? ${ }^{66}$ Odgovor je sljedeći: ako smatramo da je znanost uspješna — što je nedvojbeno bio Kuhnov stav, a također je i stav velike većine filozofa znanosti — tada možemo zaključiti da je dobro da funkcionira upravo na način na koji funkcionira. Naime, funkcionirajući na određeni način, koji se postepeno razvio pod različitim utjecajima, kako unutarnjima, tako i vanjskima, znanost se pokazala izuzetno uspješnom; stoga možemo zaključiti da je i dobro da tako funkcionira, i da znanstvenici i dalje trebaju postupati kako postupaju. Metametodološki principi koji određuju znanstvenu praksu opravdavaju se, dakle, pragmatički i aposteriorno. ${ }^{67}$ Također, na ovaj se način mogu opravdati ne samo ti principi, već i pojedine metode koje se pokažu uspješnima, kao i način funkcioniranja znanosti općenito.

Time smo, međutim, stigli i do ograničenja ovog pristupa. Naime, valja naglasiti hipotetski karakter gornjeg zaključka - ako smatramo da je znanost uspješna, onda je time opravdan i njen način funkcioniranja. Ako i prihvaćamo da je znanost uspješna, taj se uspjeh može problematizirati na nekoliko razina. Za početak, možemo se složiti da je znanost uspješna u nekim segmentima, a negirati da je uspješna u drugima. Pozicija izložena u ovom radu primjerice prihvaća da je znanost uspješna $u$ (novim) predviđanjima, manipulaciji prirodom $i$ konstrukciji eksplanatorno moćnih teorija, ali istovremeno negira da znanost otkriva strukturu svijeta po sebi te da se sve više približava istini. Nadalje, neovisno o ovdje zastupanoj poziciji, kao i općenito o raspravi o realizmu i antirealizmu, ostaje i pitanje koje će se znanosti smatrati uspješnima, a koje ne, pa, primjerice, neki koji fiziku smatra-

66 Kuhnu se još od SZR prigovaralo da miješa deskriptivno i normativno, usp. Godfrey-Smith (2003): 79, 81, 90. Kuhn je na taj prigovor odgovorio u "Postscriptu" (SZR 215-216), ali taj je odgovor, po mome sudu, prilično nejasan. Pitanjem normativnosti vrijednosti Kuhn se pozabavio u kasnijem tekstu "Rationality and Theory Choice" (RSS 208-215), ali ni tu raspravu ne smatram zadovoljavajućom budući da se može svesti na tvrdnju da, ako se znanstvenici u svom radu ne bi vodili tim vrijednostima, tada se takva 'znanost' ne bi uopće mogla nazvati znanošću.

67 Istovremeno, s obzirom da se negira sposobnost znanosti da otkriva svijet po sebi, pitanje koliko su pojedini metametodološki principi ili pojedine metode adekvatni da nam pruže spoznaju o svijetu po sebi te bi li neki druge principi ili metode bili adekvatniji kao alati otkrivanja istine, postaje bespredmetnim u raspravama o (meta)metodologiji. 
ju izuzetno uspješnom istovremeno dovode u sumnju uspješnost (i uopće znanstvenost) psihologije. Uz to, teza o opravdanosti postojeće znanstvene prakse očito uključuje tezu da znanost treba prepustiti znanstvenicima - ako postoji neki problem koji ulazi u djelokrug znanosti, tada naprosto trebamo prepustiti znanstvenicima da ga riješe. Jasno je, međutim - a također neovisno o raspravi o realizmu i antirealizmu — da uvijek ostaje pitanje je li uopće dobro da se neko istraživanje izvrši: ako rješenje problema nuklearne fuzije i treba naprosto prepustiti znanstvenicima, razvoj nuklearnog oružja svakako je u najmanju ruku upitne poželjnosti. Konačno, otvorenim ostaje pitanje u kojim se sferama prirodnim znanostima treba priznati primat - primjerice, iako znanstvenici zasigurno jesu jedini mjerodavni po pitanju nuklearne fuzije, ostaje razloga za skepsu prema pretenzijama evolucijske biologije da u potpunosti objasni moral.

\section{Zaključak}

U ovome sam radu pokušao dati jedan antirealistički odgovor na problem uspješnosti i napretka znanosti na temelju teorije znanosti Thomasa Kuhna. Iako, prema iznesenoj poziciji, povijest znanosti nije povijest napretka prema istini i sve većeg razotkrivanja strukture samog svijeta, znanost ipak može napredovati iz dvaju razloga. Prvi je taj što se različite konceptualne sheme koje se međusobno izmjenjuju odnose na vanjski svijet i njega interpretiraju. One su stoga ograničene u svome sadržaju, pa iako postoji više različitih mogućih konceptualnih shema za isti odsječak stvarnosti, one ne mogu biti proizvoljno konstruirane. Drugi je razlog taj što nove paradigme, a s njima i nove konceptualne sheme, ne nastaju u vakuumu. Nova paradigma nastaje na tlu stare i zamjenjuje ju kada stara paradigma prestane adekvatno opisivati pojave koje bi trebala opisati. Nova je paradigma stoga izravan pokušaj rješenja problema koje stara paradigma nije uspjela riješiti, ali ona istovremeno mora, ako želi biti prihvaćena, dati adekvatan odgovor i na niz problema koje stara paradigma jest uspjela riješiti te ujedno biti u tome uspješnija od suparničkih novih paradigmi. Znanstvenici dakle na novu paradigmu ne nailaze slučajno nakon besciljnog lutanja teorijskim bespućima, već je formuliraju kao odgovor na konkretne probleme i pokušaj objašnjenja konkretnih pojava, a paradigma se prihvaća tek ako uspije odgovoriti na relevantne izazove i u tome se pokaže uspješnijom kako od stare, tako i od novih suparničkih paradigmi. Time ova pozicija s jedne strane odgovara na realistički izazov argumenta bez čuda, a s druge strane dodaje pozitivan sadržaj 
pesimističkoj indukciji iz povijesti znanosti tako što nudi put objašnjenju kako je moguće odbacivanje teorija koje su u jednom trenutku bile izuzetno uspješne i općeprihvaćene. đI 


\section{LITERATURA}

Bird, Alexander (2012): “The structure of scientific revolutions and its significance: An essay review of the fiftieth anniversary edition”. British Journal for the Philosophy of Science 63, 859-883.

Brockman, John (ur.) (2015): This Idea Must Die: Scientific Theories That Are Blocking Progress. New York: Harper Perennial.

Button, Tim (2013): The Limits of Realism. Oxford: Oxford University Press.

Davidson, Donald (1973): “On the Very Idea of a Conceptual Scheme”, Proceedings and Addresses of the American Philosophical Association, Vol. 47, 5-20.

Godfrey-Smith, Peter (2003): Theory and Reality. An Introduction to the Philosophy of Science. Chicago, London: The University of Chicago Press. Hacking, Ian (1983): Representing and intervening. Cambridge University Press (25th printing 2010).

Hacking, Ian (1993): "Working in a New World: The Taxonomic Solution".

U: Horwich, Paul (ur.): World Changes. Thomas Kuhn and the Nature of Science. London, Cambridge, M.A.: The MIT Press, 275-310.

Holland, Peter R. (1993): The Quantum Theory of Motion. Cambridge: Cambridge University Press.

Hoyningen-Huene, Paul (1989): Die Wissenschaftsphilosophie Thomas S. Kuhns: Rekonstruktion und Grundlagenprobleme. Wiesbaden: Springer Fachmedien.

Kožnjak, Boris (2013): Eksperiment i filozofija. Zagreb: KruZak.

Kuhn, Thomas S. (1993): “Afterwords”. U: Horwich, Paul (ur.): World Changes. Thomas Kuhn and the Nature of Science. London, Cambridge, M.A.: The MIT Press, 311-341.

Kuhn, Thomas S. (1977): [ET] The Essential Tension. Selected Studies in Scientific Tradition and Change. Chicago, London: The University of Chicago Press.

Kuhn, Thomas S. (2000): [RSS] The Road Since Structure. Philosophical Essays, 1970-1993, with an Autobiographical Interview. Chicago, London: The University of Chicago Press.

Kuhn, Thomas S. (2002): Struktura znanstvenih revolucija (2. hrvatsko izdanje). Zagreb: Naklada Jesenski i Turk, prevela Mirna Zelić.

Kukla, Andre (1996): "Antirealist Explanations of the Succes of Science”.

Philosophy of Science, vol.63, Supplement. Proceedings of the 1996 Biennial Meetings of the Philosophy of Science Association. Part I: Contributed Papers, 298-305.

Laudan, Larry (1981): “A confutation of convergent realism”. Philosophy of Science 48, 19-49. 
Lynch, Michael P. (1997): "Three Models of Conceptual Schemes". Inquiry 40, 407-426.

Putnam, Hilary (1975): Mathematics, Matter, and Method. Cambridge, M.A.: Harvard University Press.

Putnam, Hilary (1987): “Truth and Convention: On Davidson's Refutation of Conceptual Relativism”. Dialectica, $\mathrm{Vol}_{41}$., $\mathrm{N}^{\circ}{ }_{1-2}, 69-77$.

Putnam, Hilary (2012): "From Quantum Mechanics to Ethics and Back Again”. U: Putnam, Hilary (aut.); De Caro, Mario; Macarthur, David (ur.): Philosophy in an age of Science. Physics, Mathematics and Skepticism. Cambridge, M.A., London: Harvard University Press, 51-71.

Rockmore, Tom (2006): "Kuhn, Different Worlds and Science as Historical". U: Rockmore, Tom, Margolis, Joseph (ur.): History, Historicity and Science. Hampshire: Ashgate, 167-186.

Taylor, Kenneth. A (2011): “Conceptual Relativism”. U: Hales, Steven D. (ur.): A Companion to Relativism. Wiley-Blackwell, 159-178.

Vickers, Peter (2018): "Historical challenges to realism”. U: Saatsi, Juha (ur.): The Routledge Handbook of Scientific Realism. London, New York: Routledge, 48- 59 .

Wang, Xinli (2009): “On Davidson's Refutation of Conceptual Schemes and Conceptual Relativism". Pacific Philosophical Quarterly 9o, 140-164. Wray, K. Brad (2018): "Success of science as a motivation for realism". U: Saatsi, Juha (ur.): The Routledge Handbook of Scientific Realism. London, New York: Routledge, 37-47. 